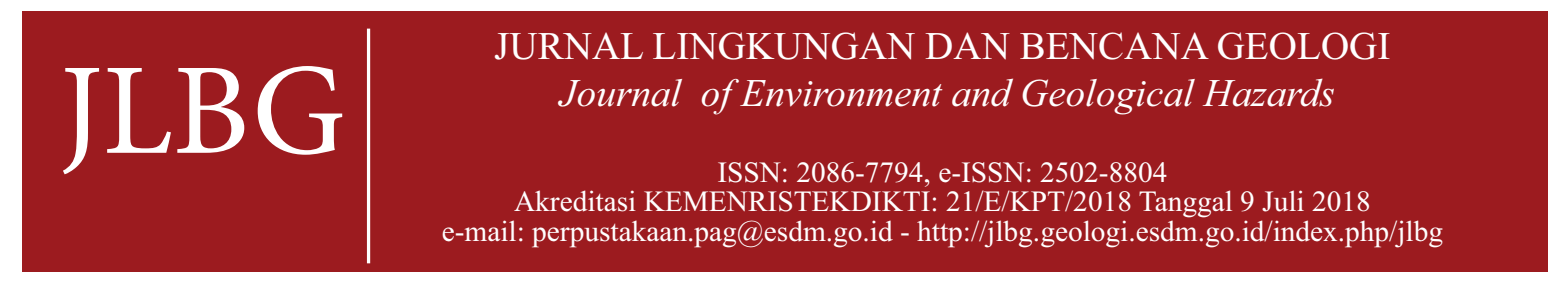

\title{
Analisis Potensi Gempa di Selatan Pulau Jawa Berdasarkan Pengamatan GPS
}

\section{Analysis of Earthquake Potential in the South of Java Island Based on GPS Observations}

\author{
Irwan Meilano ${ }^{1,2}$, Agidia L. Tiaratama ${ }^{1}$, Dudy D. Wijaya ${ }^{1}$, Putra Maulida ${ }^{3}$, S. Susilo ${ }^{4}$, Intan H. Fitri ${ }^{1}$ \\ ${ }^{1}$ Fakultas Ilmu dan Teknologi Kebumian, Institut Teknologi Bandung \\ ${ }^{2}$ Pusat Unggulan Ipteks - Perguruan Tinggi (PUI-PT), Center for Earthquake Science and Technology \\ Institut Teknologi Bandung, Indonesia \\ ${ }^{3}$ Departemen Teknik Geomatika, Fakultas Teknik Sipil Lingkungan dan Kebumian \\ Institut Teknologi Sepuluh Nopember, Indonesia \\ ${ }^{4}$ Badan Informasi Geospasial, Cibinong, Indonesia \\ e-mail: irwanm@itb.ac.id
}

Naskah diterima 1 November 2020, selesai direvisi 20 Desember 2020, dan disetujui 21 Desember 2020

\begin{abstract}
ABSTRAK
Pulau Jawa merupakan salah satu pulau yang memiliki kepadatan penduduk tinggi dengan aktivitas tektonik yang sangat aktif. Hal ini dikarenakan Pulau Jawa terletak di zona konvergensi Lempeng Indo-Australia dan Lempeng Eurasia. Aktivitas tektonik ini menghasilkan kegempaan di zona subduksi dan sesar di daratan Penelitian ini menganalisis pola vektor kecepatan yang dihasilkan melalui pengolahan data stasiun pengamatan GPS (Global Positioning System) CORS (Continuously Operating Reference Station) BIG (Badan Informasi Geospasial) di wilayah Pulau Jawa bagian selatan. Data koordinat harian dianalisis dengan metode PCA (Principal Component Analysis) untuk memisahkan sinyal tektonik berupa data deret waktu global dan non-tektonik berupa data deret waktu lokal dengan penerapan aturan pemilihan varian dominan nilai eigen dalam pembetukan PC (Principal Component) dan orthogonal vektor eigen sebagai bobot dalam meminimalkan korelasi. Hasil dari data deret waktu global dan lokal digunakan untuk menghitung besar kecepatan pergeseran dari tahun 2011 sampai 2018. Hasil pengolahan menunjukkan besar resultan vektor kecepatan pada data awal berselang 0,06 sampai 10,46 mm/tahun, pada data global antara $0,06 \mathrm{~mm} /$ tahun sampai 10,39 mm/tahun, dan data lokal sebesar 0,0037 sampai 1,99 mm/tahun. Variasi spasial vektor kecepatan pengamatan GPS data domain PCA menunjukkan variasi pergeseran horizontal di wilayah Banten bergerak ke arah timur laut; Jawa Barat, Daerah Istimewa Yogyakarta, dan Jawa Tengah bergerak ke arah tenggara; dan Jawa Timur bergerak ke arah timur laut. Hasil dari inversi data pergeseran terhadap slip pada zona subduksi, menunjukkan terjadinya kekurangan slip atau terjadi coupling pada zona subduksi Jawa bagian timur dan barat, sementara terjadi kelebihan slip pada bagian tengah yang merupakan efek postseismic dari gempa Pangandaran 2006.
\end{abstract}

Kata kunci: GPS, PCA, potensi gempa, vektor kecepatan

\section{ABSTRACT}

Java is one of the island that has a high population density with very active tectonic activity. This is because Java Island is located in the convergence zone of the Indo-Australian Plate and the Eurasian Plate. This tectonic activity produces seismicity in subduction zones and inland faults. This study analyzes the velocity vector patterns generated through data processing of the GPS (Global Positioning System) CORS (Continuously Operating Reference Station) BIG (Geospatial Information Agency) observation station in the southern part of Java. Daily coordinate data were analyzed using PCA (Principal Component Analysis) method to separate time series of tectonic signals as global data and non-tectonic time series data as local data by applying the rules for selecting dominant variants of eigen values for PC formation and orthogonal eigen vectors as weights in minimizing correlations. The results from global and local time series data were used to calculate the magnitude of the displacement velocity from 2011 until 2018. The processing results show the resultant velocity vector in the initial data intermittent 0.06 to $10.46 \mathrm{~mm} /$ year, global data from 0.06 to $10.39 \mathrm{~mm} /$ year, and local data of 0.0037 to $1.99 \mathrm{~mm} /$ year. The spatial variation of the velocity vector in 
PCA domain data shows the horizontal displacement in the Banten region to the northeast; West Java, Yogyakarta Special Region, Central Java to southeast; and East Java moving to northeast. The results of the inversion of the surface displacement to slip data in the subduction zone show that there is a slip deficiency or coupling occurs in the subduction zones of Eastern and Western Java, while there is excess slip in the Central Java which is a post-seismic effect of the 2006 Pangandaran earthquake.

Keywords: earthquake potential, GPS, PCA, velocity vector

\section{PENDAHULUAN}

Berdasarkan data kegempaan merusak, Pulau Jawa telah mengalami 48 gempa besar dari tahun 1612 hingga 2014 (Supartoyo drr, 2014). Beberapa gempa dengan magnitudo lebih dari 7 berhubungan dengan zona subduksi yang terletak di bagian selatan Jawa (Newcomb dan McCann, 1987). Zona tersebut merupakan batas lempeng aktif yang mengakomodasi tumbukan lempeng Indo-Australia dan lempeng Eurasia dengan laju konvergensi normal $58.3 \pm 0.5 \mathrm{sam}-$ pai $61.8 \pm 0.4 \mathrm{~mm} /$ tahun di selatan Jawa Barat (Koulali drr, 2016). Pulau Jawa memiliki risiko bahaya seismik yang tinggi karena berada pada zona subduksi dan berpenduduk padat. Oleh karena itu, pemahaman yang lebih baik mengenai potensi dan tingkat coupling pada bidang antarlempeng di zona subduksi Jawa menjadi sangat penting. Risiko bencana lainnya di Pulau Jawa berasal dari sesar aktif di daratan seperti salah satunya adalah Sesar Lembang (Meilano drr, 2012 dan Meilano drr, 2020).

Untuk memahami kondisi tektonik Jawa sebagai bagian dari upaya mitigasi maka dilakukan pengamatan GPS guna mengidentifikasi pola dan besar deformasi di pulau ini. Penelitian ini bertujuan untuk mengetahui potensi gempa di zona subduksi selatan Pulau Jawa berdasarkan variasi spasial pergeseraan GPS untuk komponen horizontal dan vertikal. Data pergeseran titik pengamatan GPS dianalisis dengan menggunakan metode PCA (Principal Component Analysis) untuk mendapatkan pola pergerakan tektonik dan nontektonik (Dong drr, 2006 dan He drr, 2015).

Potensi gempa diestimasi dengan menghitung besarnya slip pada zona subduksi menggunakan inversi data GPS hasil pengolahan PCA. Inversi dilakukan dengan menggunakan metode $\mathrm{ABIC}$ (Akaike Bayesian Information Criterion) (Ya- buki dan Matsu'ura, 1992). Metode ini menggunakan data pergeseran di selatan Jawa yang digabungkan dengan nilai kendala kekasaran distribusi slip, untuk merekonstruksi distribusi spasial dari slip pada bidang subduksi.

\section{METODE PENELITIAN}

Penelitian ini menggunakan metode PCA(Dong drr, 2006) untuk mendapatkan hasil variasi vektor kecepatan di wilayah selatan Pulau Jawa berdasarkan data pengamatan GPS. Pengolahan data GPS-nya menggunakan perangkat lunak GAMIT/GLOBK versi 10.7 (Herring, drr. 2018) yang dikembangkan oleh MIT (Massachusetts Institute of Technology). Data GPS berasal dari pengamatan tahun 2011 hingga 2018 pada stasiun BIG (Badan Informasi Geospasial). Stasiun pengamatan yang digunakan dalam penelitian berada di bagian selatan Pulau Jawa dengan jumlah 13 stasiun, yaitu CMLP, CMIS, CPTU, CTAN, CRUT, CCLP, CKBM, CBTL, CNYU, CTUL, CLUM, CJEM, CPES dengan sebaran yang dapat dilihat dalam Gambar 1.

Pada penelitian ini, penghapusan outlier dilakukan dengan menggunakan uji statistik metode t-student (Ghilani dan Charles, 2010) dimana digunakan selang kepercayaan 95\% dan dua sigma $(2 \sigma)$ dari rata-rata seluruh data. Penghilangan efek rotasi blok Sunda dilakukan dengan dengan menggunakan parameter Kutub Euler dari Kuncoro drr (2019) berupa lintang $46.2^{\circ} \mathrm{N}$, bujur $89.4^{\circ} \mathrm{W}$, dan kecepatan sudut $0.327^{\circ} / \mathrm{Myr}$ dengan pergerakan rotasi blok yang berlawanan arah jarum.

Dalam deret waktu hasil pengamatan GPS tidak hanya mengandung sinyal tektonik, tetapi juga terdapat sinyal non-tektonik didalamnya selain kesalahan yang tidak termodelkan (He drr, 


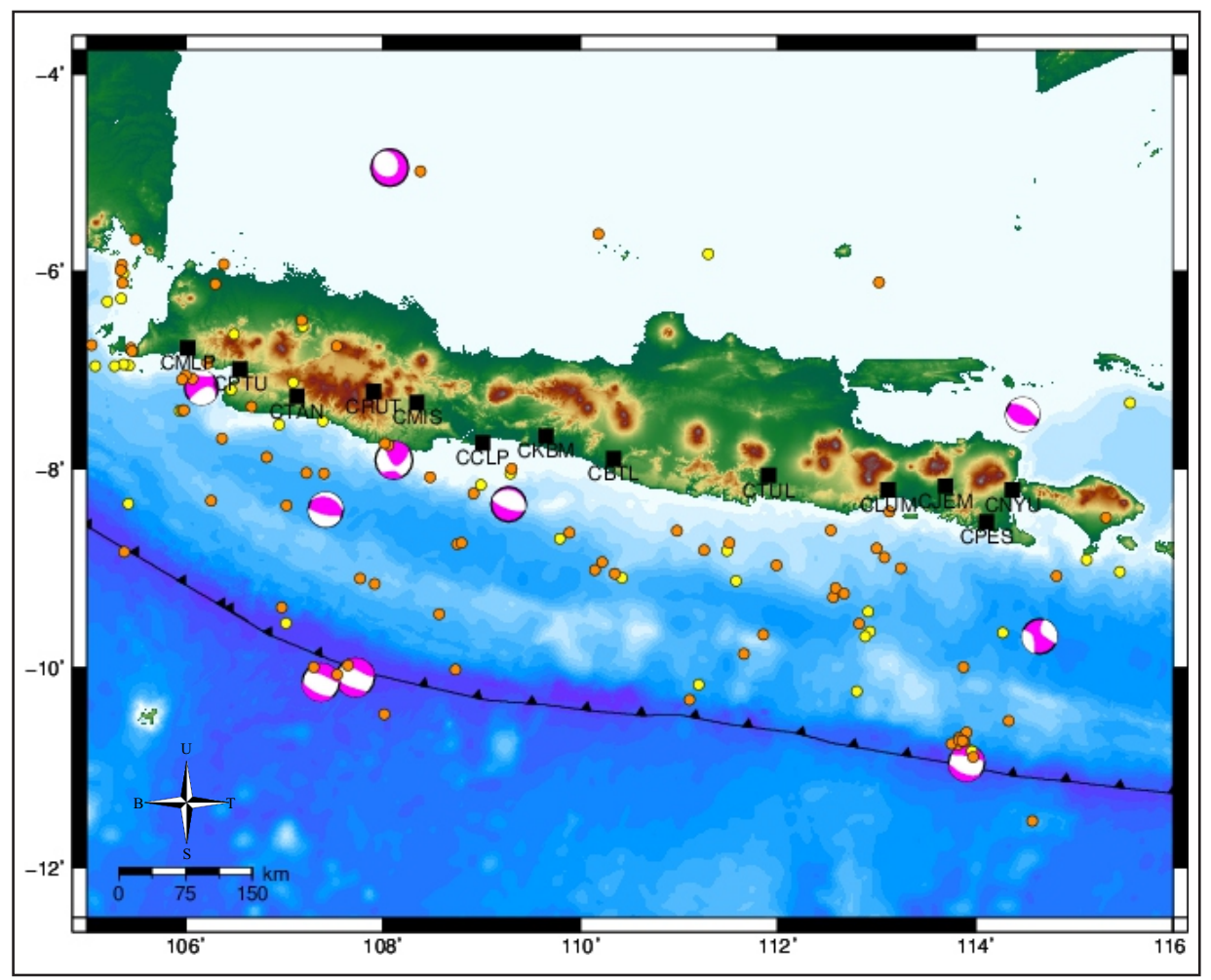

Gambar 1 Sebaran titik kegempaan, mekanisme fokal gempa (warna merah muda), dan persebaran titik pengamatan GPS kontinyu CORS BIG yang digunakan dalam penelitian. Titik lokasi pengamatan GPS ditunjukkan dalam bentuk persegi hitam, sedangkan lokasi pusat gempa digambarkan dengan warna kuning untuk magnitudo 5 dan orange untuk magnitudo antara 5 sampai 6 .

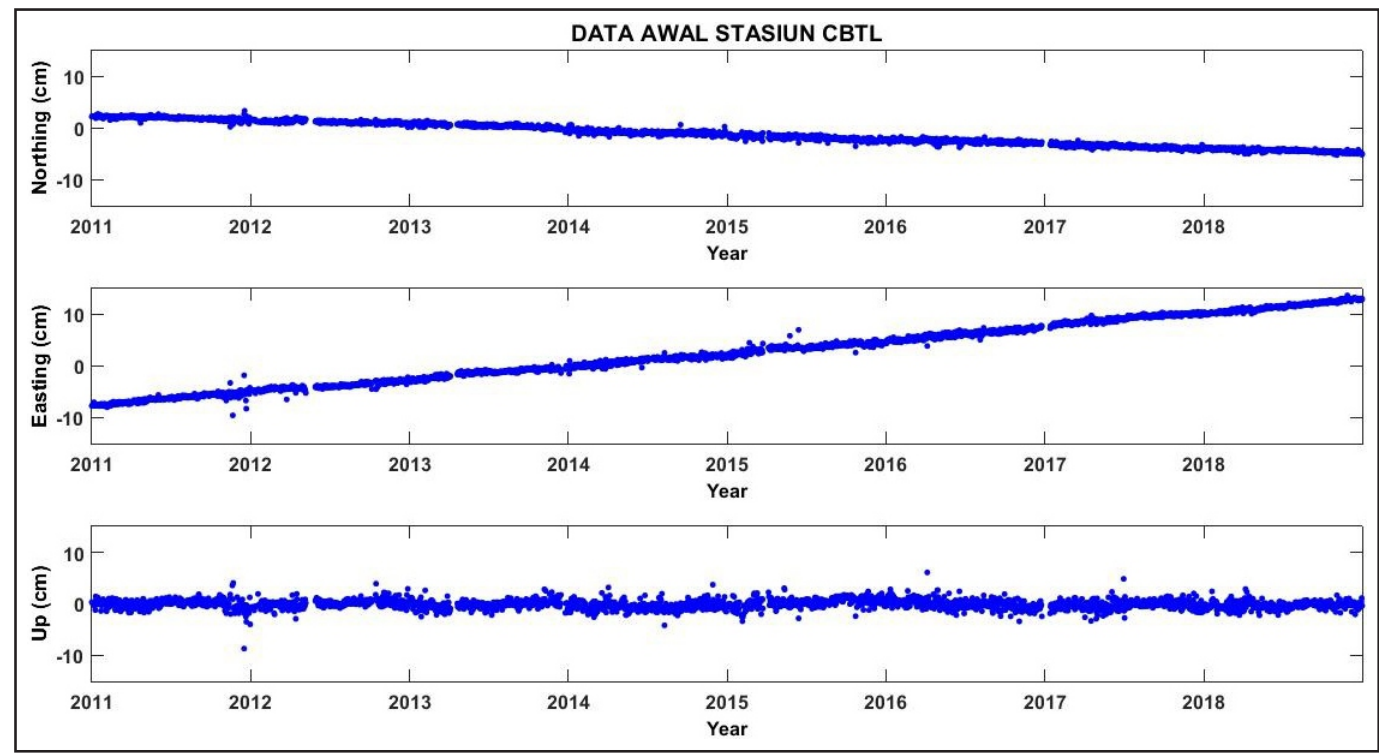

Gambar 2 Deret waktu stasiun pengamatan GPS kontinya titik CBTL.

2015). Salah satu sinyal non-tektonik yang ada berupa sinyal berpola dari efek musiman berupa efek tahunan dan efek setengah-tahunan. Efek tersebut dapat dihilangkan dengan melakukan proses ekstraksi nilai efek musiman berupa fungsi trigonometris. Efek musiman tersebut bisa dihitung menggunakan persamaan (1) sebagai berikut. (Nikolaidis, 2002). 
$y\left(t_{i}\right)=a+b t_{i}+c \sin \left(2 \pi t_{i}\right)+d \cos \left(2 \pi t_{i}\right)+e \sin \left(4 \pi t_{i}\right)+f \cos \left(4 \pi t_{i}\right)$

Dimana $y(t)$ adalah fungsi pergeseran titik pada $t_{i} t_{i}$ pada epok $i=1$ sampai ke-n dalam satuan tahun, $a$ merupakan koordinat awal stasiun GPS, $b$ merupakan laju pergeseran dalam satuan meter/tahun, $c$ dan $d$ merupakan koefisien dari pergerakan yang bersifat periodik tahunan, $e$ $\operatorname{dan} f$ merupakan koefisien dari pergerakan yang bersifat periodik semi-tahunan.

Data deret waktu yang telah bebas dari outlier dan kesalahan sistematik kemudian dianalisis untuk menghasilkan vektor kecepatan pergeseran. Adapun persamaan linier yang digunakan dalam perhitungan, berupa :

$y(t)=a+b t$

Selanjutnya dilakukan pengolahan dengan metode PCA dengan mengatur data dalam matriks baris berupa data harian dan kolom untuk setiap stasiun. Untuk data harian yang memiliki pengamatan kurang dari 3 hari dapat diisi dengan interpolasi kubik spline (Ghilani dan Charles, 2010) dan diatas 3 hari dengan interpolasi linier untuk mempertahankan tren data.

Menggunakan matriks hasil variansi-kovariansi, dilakukan perhitungan nilai eigen dan vektor eigen. Nilai eigen ini dijadikan sebagai bobot spasial dengan jumlah 13 untuk pembuatan data domain PCA dengan penjelasan keragaman data didalamnya Dengan mengasumsikan bahwa $X$ adalah data asli $n$ (berupa banyak pengamatan) oleh $p$ (variabel), matriks data terpusat seperti dijelaskan pada Smith (2002). Matriks kovarian $C$ dari matriks data dinyatakan dalam persamaan (3):

$c=\frac{X^{T} X}{(n-1)}$

Matriks kovarians $(C)$ menggambarkan hamburan data, rentang rata-rata dan korelasi antar variabel. $\mathrm{C}$ adalah matriks simetris, dan bentuk diagonal dalam (4):

$C=V L V^{T}$

di mana $\boldsymbol{V}$ adalah matriks yang terdiri dari vektor eigen di kolomnya, dan $\boldsymbol{L}$ adalah matriks nilai eigen $\boldsymbol{i}$ pada diagonal, dalam urutan menurun (persamaan 5).

$A V=\lambda V$

di mana nilai skalar adalah nilai eigen yang terkait dengan vektor eigen $\boldsymbol{V}$.

Demikian pula, dekomposisi nilai singular $\boldsymbol{X}$ :

$X=U S V^{T}$

Kemudian nilai eigen pada PC (persamaan 6), diurutkan sesuai dengan keragaman datanya. Nilai korelasi diestimasi dari besarnya persentase nilai eigen diatas $90 \%$ dengan mengasumsikan bahwa persentase memiliki keeratan hubungan dalam data yang kemudian diaplikasikan untuk memperoleh nilai PC baru yaitu PC1 dan PC2. Dengan penerapan aturan ini, hanya beberapa PC yang berpotensi menjadi mode utama/umum karena semakin besar nilai PC semakin berkait ke sedikit stasiun dan dapat diduga menggambarkan efek lokal. Sehingga, PC baru kemudian digunakan sebagai bobot spasial data baru untuk data global dan data lokal berupa PC1 dan PC2.

Kemudian dilakukan perhitungan data global dan data lokal menggunakan data inputan yang sebelumnya untuk menghitung PC kemudian dikalikan dengan PC1 dan PC2 (persamaan 7).

$X V=U S V^{T} V=U S$

Untuk memastikan bahwa langkah yang dilakukan benar, maka dilakukan pengujian untuk mengembalikan data pada domain PCA dan hasilnya harus sama dengan data awal (persamaan 8,9 dan 10). 
$X=X V V^{T}=U S V^{T}$

Akhirnya, set data baru dapat diturunkan sebagai:

Final Data $=$ Feature Vector ${ }^{T} X^{T}$

atau serupa, dengan memilih $\mathrm{m}$ kolom pertama $\mathrm{U}$, dan $m$ oleh $m$ bagian kiri atas S:

Final Data $=U_{n x m} S_{m x m}$

\section{HASIL DAN PEMBAHASAN}

Dalam pengamatan deformasi melalui data GPS, PCA menjadi spatiotemporal filtering yang digunakan untuk mengurangi atau memisahkan bahkan menghapus nilai common mode error (CME) dalam data pengamatan dan dapat meningkatkan signal-to-noise ratio (SNR) dari deret waktu GPS jaring regional di Pulau Jawa. Berdasarkan hasil persentase setiap nilai eigen, banyaknya $\mathrm{PC}$ yang dipakai sebanyak tiga angka berupa PC1, PC2, dan PC3 diartikan sebagai $\mathrm{PC} 1$ variabel pembentuk data global, PC2 variabel pembentuk data lokal, dan PC3 dibuat bernilai 0 agar memudahkan pembacaan visualisasi. Pada Gambar 3 komponen $\mathrm{dN}$ menggunakan variabel nilai eigen sebesar $0,0006257(92,1618 \%)$ untuk PC1 dan 0,0000532 (7,8382\%) untuk PC2. Komponen
dE pada Gambar 3 nilai variabel nilai eigen sebesar 0,0007697 $(91,1548 \%)$ untuk PC1 dan 0,0000747 (8,8452\%) untuk PC2. Pada Gambar 5 komponen dU menggunakan variabel nilai eigen sebesar 0,0013786 $(92,3596)$ untuk PC1 dan 0,000114 (7,6404\%) untuk PC2.

Data deret waktu hasil PCA menampilkan data dalam domain global dan lokal yang memberikan gambaran kecenderungan di setiap komponen pergerakannya untuk tiga belas stasiun pengamatan. Gambar 4 menjelaskan visualisasi stasiun CBTL untuk data global (biru) yang menjelaskan pergerakan tektonik dari dari tiga komponen dan data lokal (merah) menggambarkan sinyal non-tektonik stasiun.

Gambar 4 hasil deret waktu domain PCA memperlihatkan metode ini bisa memperhalus data dengan mengurangi kesalahan sistematis. Pada komponen arah vertikal kemungkinan masih berisi kesalahan acak dan non-deformasi tektonik berupa koreksi yang masih kurang tepat pada pasut (solid earth tides, pole tides, dan ocean tides) dalam proses pengolahan dengan GAMIT/GLOBK karena beberapa stasiun berada di dekat laut (Liu drr, 2015).

Berdasarkan Gambar 5 vektor komponen horizontal di Jawa Barat bergerak ke arah timur, timur laut, dan tenggara. Jawa tengah ke arah timur, dan Jawa Timur ke arah timur laut. Variasi secara vertikal (Gambar 6) berupa kenaikan dan

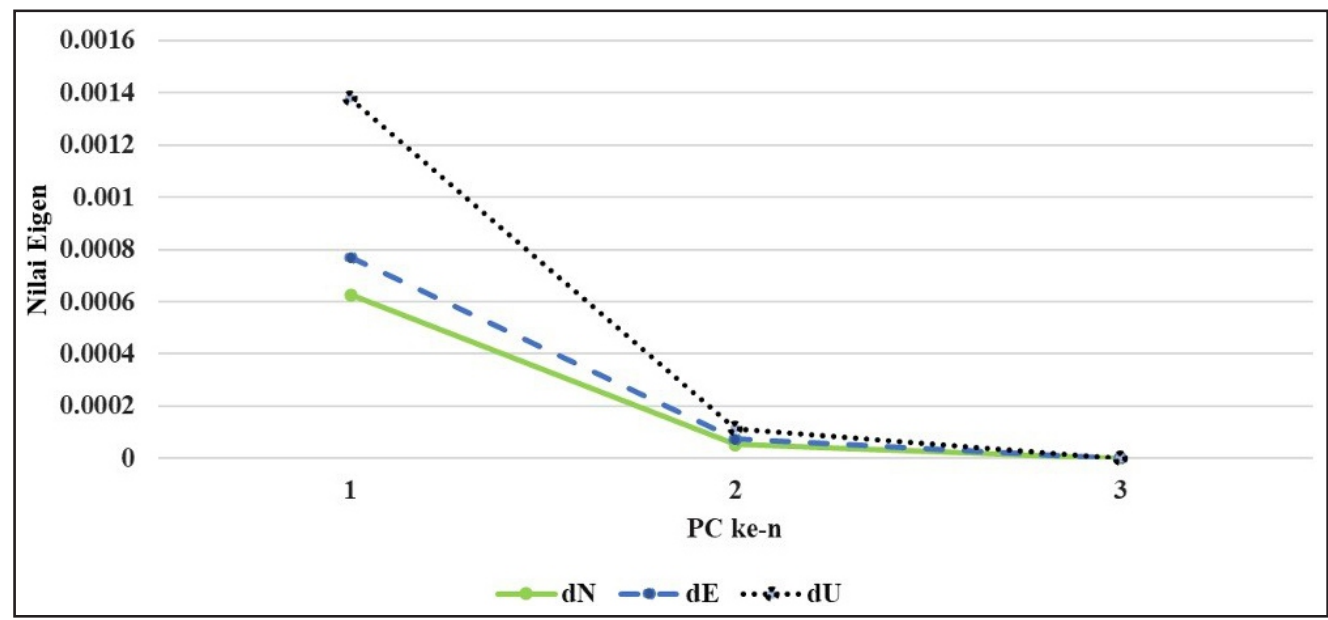

Gambar 3 Nilai eigen komponen utara selatan $(\mathrm{dN})$, timur barat (dE), dan vertikal (dU) untuk setiap PC. 


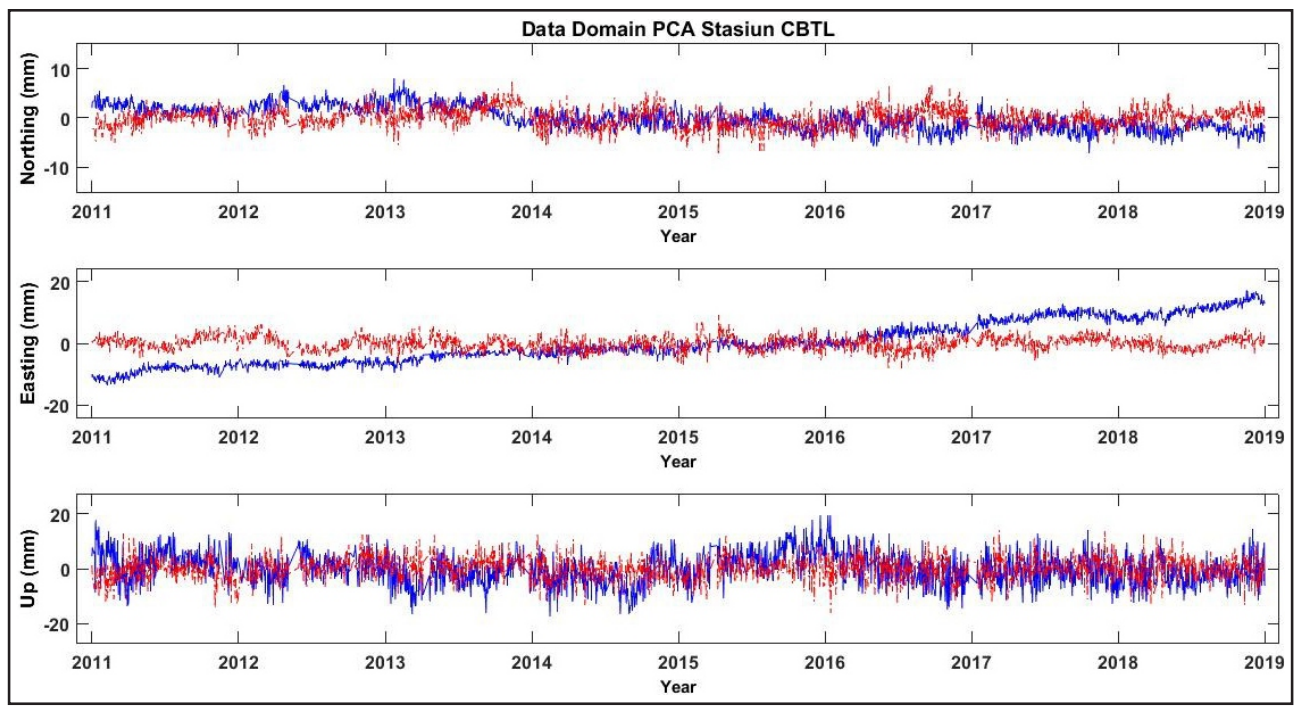

Gambar 4 Deret waktu domain PCA untuk setiap komponen, data global (berwana biru) dan data lokal (berwarna merah) dari stasiun pengamatan CBTL.

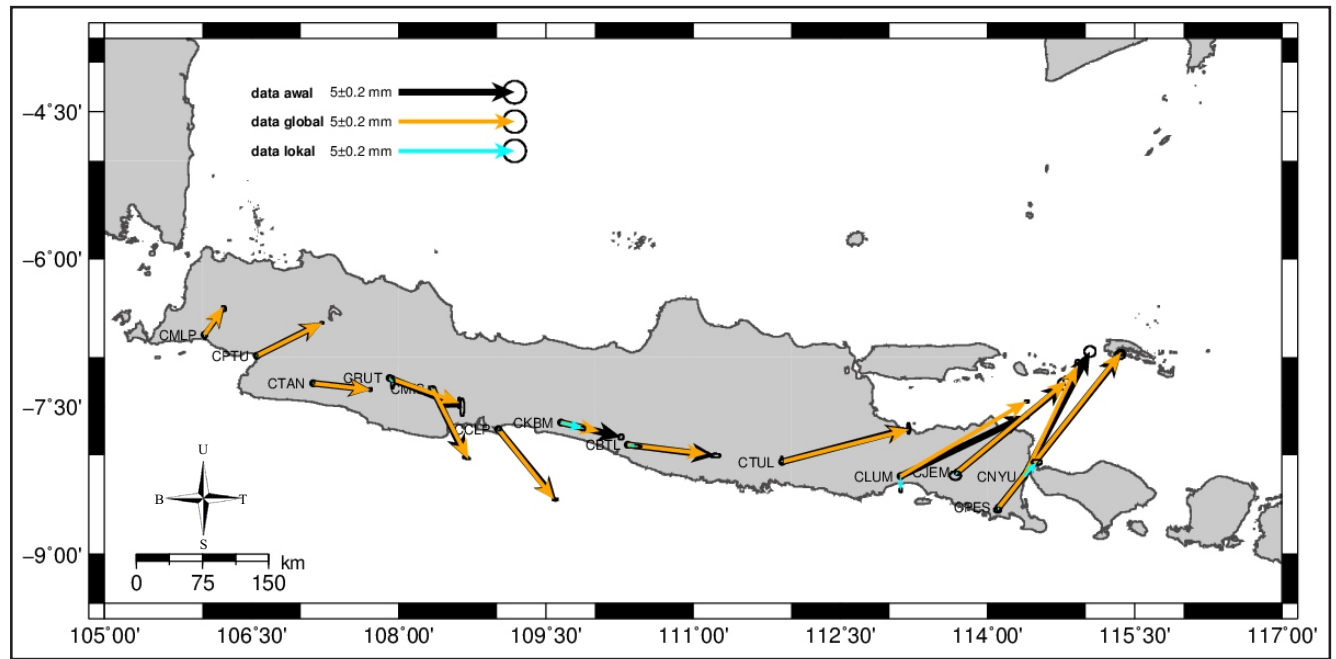

Gambar 5 Vektor kecepatan komponen horizontal stasiun dari data awal dan data domain PCA.

penurunan bervariasi terjadi di semua wilayah selatan Jawa.

Variasi yang terbentuk ini memisahkan selatan Jawa menjadi tiga wilayah yaitu wilayah Selat Sunda hingga selatan Jawa Barat, selatan Jawa Tengah, serta selatan Jawa Timur hingga Bali. Pola pergerakan berbeda dari wilayah barat Jawa bagian selatan ini terjadi di CTAN, CRUT, CMIS Jawa Barat dan sebagian Jawa Tengah, CCLP yang bergerak ke arah tenggara. Pergerakan secara vertikal mengalami penurunan, kecuali di CCLP dengan besar kecepatan yang cukup terlihat signifikan.
Titik pengamatan GPS di selatan Jawa Tengah dan DIY bergerak ke arah tenggara timur dan pengalami penaikan posisi vertikal. Pada wilayah Bantul pergerakan tersebut dipicu dengan adanya Sesar Opak, sesar yang diduga aktif kembali saat peristiwa gempa Yogya 2006 silam, berbentuk gawir memanjang arah barat daya-timur laut membelok ke timur ke sesar naik batur agung yang sudah tidak aktif (Pusgen, 2017). Sesar Opak ini juga mengalami pergeseran sinistral dengan bidang sesar yang tidak tegak lurus (Natawidjaja, 2016 dalam Pusgen, 2017). Pergerakan dengan besar dan 


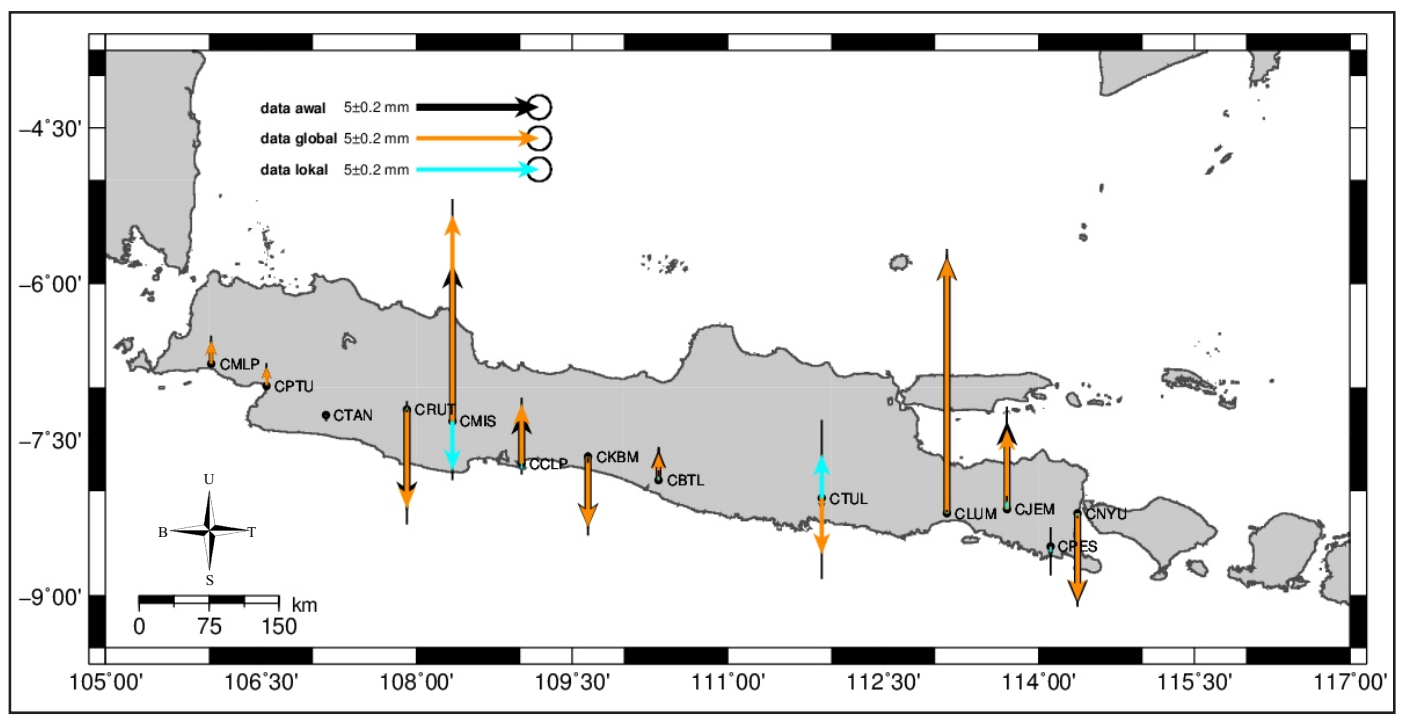

Gambar 6 Vektor kecepatan komponen vertiktal stasiun dari data awal dan data domain PCA.

arah yang bervariasi, mengindikasikan bagian selatan Pulau Jawa memiliki aktifitas tektonik yang aktif.

Untuk memahami potensi gempa pada zona subduksi dilakukan inversi dengan menggunakan 2 bidang sumber gempa, bidang pertama berukuran membentang dari bagian selatan ujung timur Pulau Jawa hingga bagian selatan Garut, Jawa Barat, dan bidang kedua membentang dari selatan Garut hingga selatan ujung barat Pulau Jawa. Kedua bidang dibagi-bagi ke dalam sub-bidang berukuran $20 \times 20 \mathrm{~km}$ (disesuaikan dengan sensitifitas terhadap data) yang masingmasing sub-bidang memiliki nilai kedalaman dan sudut kemiringan yang didapatkan dari model Slab 1.0 (Hayes drr, 2012).

Nilai laju konvergensi lempeng Indo-Australia dan lempeng Eurasia yaitu 64 mm/tahun (Koulali drr, 2016). Dengan membandingkan terhadap nilai tersebut, hasil inversi zona subduksi Jawa menunjukkan terjadinya kekurangan slip atau terjadi coupling pada zona subduksi Jawa bagian timur dan barat, sementara terjadi kelebihan slip pada bagian tengah yang merupakan efek postseismik dari gempa Pangandaran 2006. Pada Jawa bagian barat, di mana vektor pergeseran menunjukkan arah ke timur laut, terlihat bahwa slip pada bidang gempa bernilai positif yang berarti terjadi coupling. Kemudian, vek- tor berubah cenderung mendatar ke arah timur, dan terlihat bahwa nilai slip pada bidang gempa mendekati nol. Pada Jawa bagian tengah, vektor menuju ke arah tenggara, dan slip pada bidang gempa bernilai negatif yang menandakan slip yang terjadi melebihi nilai laju konvergensi. Kemudian, vektor kembali mendatar, dan nilai slip kembali mendekati nol. Selanjutnya di Jawa bagian timur, di mana vektor berukuran relatif besar mengarah ke timur laut, pada bidang gempa terjadi coupling dengan nilai yang lebih besar daripada coupling di Jawa bagian barat. Perhitungan kemuka dari model slip yang yang dhitung dengan inversi menghasilkan vektor pergeseran yang digambarkan dengan panah biru (Gambar 7). Nilai Akar kesalahan kuadrat rata-rata dari perbedaan data dengan hasil perhitungan kemuka yakni $2.679 \mathrm{~mm} /$ tahun. Pola dari hasil pergeseran pada bidang gempa ini mengindikasikan ada potensi gempa di bagian barat dan bagian timur zona subduksi selatan pulau Jawa.

Zona subduksi di selatan Pulau Jawa diketahui memiliki potensi gempa yang ditunjukan dengan adanya kekosongan kegempaan (seismic gap) (Widyantoro drr, 2020). Penelitian ini mendukung adanya seismic gap yang berpotensi menjadi di masa depan terutama pada bagian selatatan Jawa bagian barat dan bagian timur. 


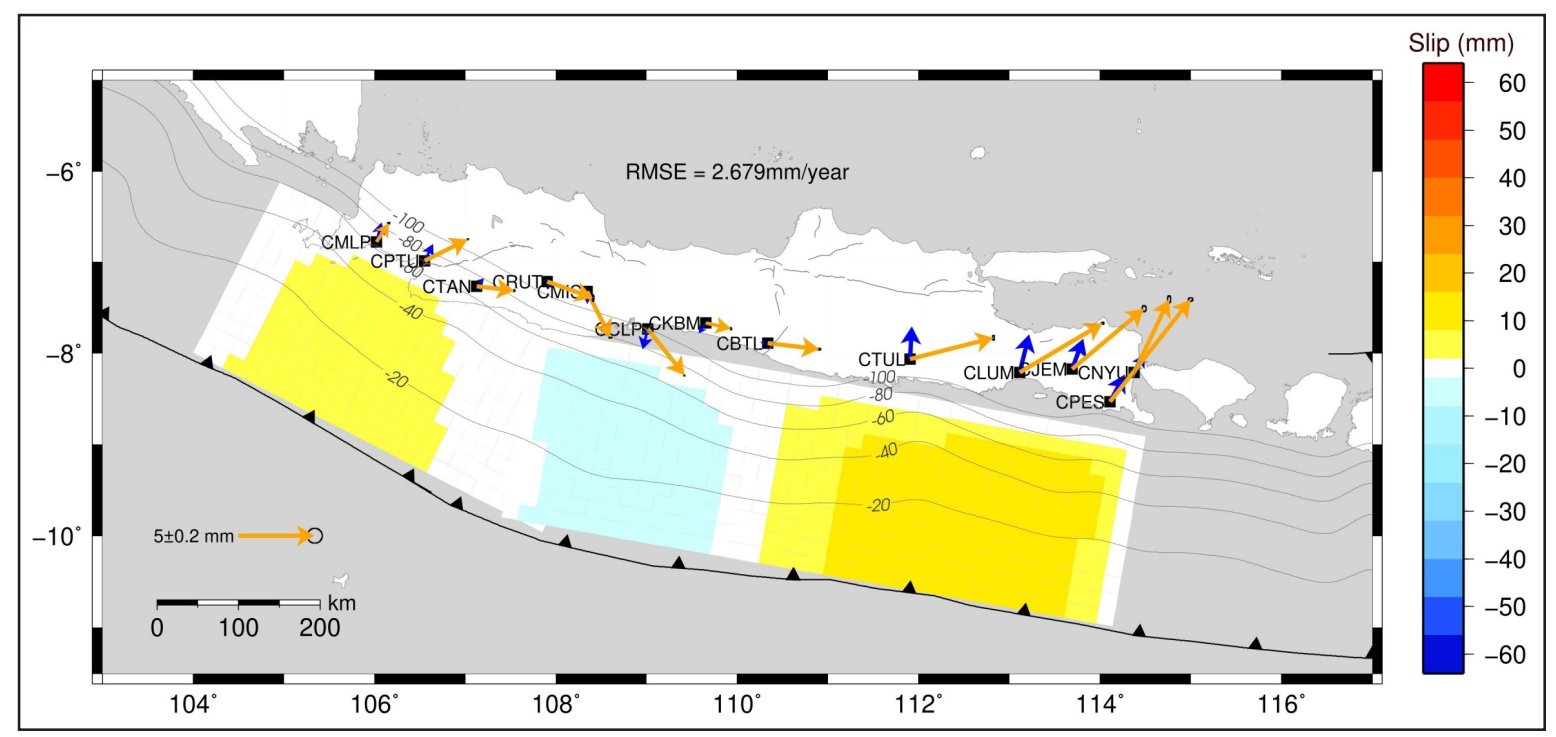

Gambar 7 Pergeseran pada bidang gempa hasil inversi Panah berwarna oranye menggambarkan vektor dari pengamatan GPS dan panah biru merupakan hasil perhitungan kemuka dari hasil inversi.

\section{KESIMPULAN}

Penggunaan metode PCA pada penelitian ini dapat memisahkan data deret waktu global berisi fenomena tektonik dan data lokal berisi kesalahan acak dan fenomena nondeformasi tektonik. Hasil ini didapatkan dengan menerapkan aturan pemilihan varian dominan nilai eigen untuk pembentukan PC sebagai variabel pemisahan data dan orthogonal vektor eigen sebagai bobot spasial dalam meminimalkan korelasi pembentukan data baru.

Hasil deret waktu global berhasil menjelaskan pengaruh tektonik dalam Pulau Jawa yang digambarkan dengan vektor kecepatan pergeseran dalam komponen horizontal dan vertikal. Dari hasil pemisahan data dengan PCA, variasi spasial vektor kecepatan pengamatan GPS Jawa bagian selatan secara horizontal bergerak ke arah timur laut pada wilayah barat dan wilayah timur. Sementara itu pada bagian tengah Jawa bergerak ke arah tenggara.

Hasil inversi data pengamatan menunjukkan terjadinya kekurangan slip atau terjadi coupling pada zona subduksi Jawa bagian timur dan barat, yang mengindikasikan adanya potensi gempa. Sementara terjadi kelebihan slip pada bagian tengah yang merupakan efek pascaseismik dari gempa Pangandaran 2006. Potensi gempa ini diharapkan menjadi bagian dari strategi pengurangan risiko bencana gempa dan tsunami di Pulau Jawa.

\section{UCAPAN TERIMA KASIH}

Penulis mengucapkan terima kasih kepada P3MI ITB tahun 2020 yang telah memberikan pendanaan pada penelitian ini

\section{DAFTAR PUSTAKA}

Dong, D., P, Fang., Bock, Y., Webb, F., Prawirodirdjo, L., Kedar, S., dan Jamason, P. 2006. Spatiotemporal filtering using principal component analysis and Karhunen-Loeve expansion approaches for regional GPS network analysis. Journal of Geophysical Research, 111, B03405, doi: 10.1029/2005JB003806.

Ghilani, Charles D. 2010. Adjustment computations Spatial Data Analysis, $4^{\text {th }}$ Edition. United States of America. John Wiley \& Sons, Inc.

Hayes, G. P., D. J. Wald, and Johnson, R. L. 2012. Slab1.0: A three-dimensional model of global subduction zone geometries. Journal of Geophysical Research, 117 (B01302). 
Herring, T.A., King, R. W., Floyd, M. A., dan McClusky, S. C. 2018. GAMIT Reference Manual Release 10.7, Department of Earth, Atmospheric, and Planetary Sciences Massachusetts Institute of Technology.

He, Xiaoxing., Hua, Xianghong., Yua, Kegen., Xuan, Wei., Lu, Tieding., W. Zhang, and X. Chen. 2015. Accuracy enhancement of GPS time series using principal component analysis and block spatial filtering. Advances in Space Research (a COSPAR publication), 55, p.1316-1327

Koulali, A., McClusky, S., Susilo, S., Leonard, Y., Cummins, P. Tregoning, P., Meilano, I., Efendi, J., and Wijanarto, A.B. 2016. The kinematics of crustal deformation in Java from GPS observations: Implications for fault slip partitioning. Earth and Planetary Science Letters, 458, 69-79. https://doi.org/10.1016/j. eps1.2016.10.039

Kuncoro, Henri., Irwan Meilano., dan Susilo. 2019. Sunda and Sumatra Block Motion in ITRF 2008. Bandung. E3S Web of Conferences 94, 04006, ISGNSS 2018. https://doi. org/10.1051/e3sconf/20199404006

Liu, Bin., Dai, Wujiao., Peng, Wei., and Meng, Xiaolin. 2015. Spatiotemporal analysis of GPS time series in vertical direction using independent component analysis. Earth, Planets and Space, 67:189. DOI 10.1186/ s40623-015-0357-1.

Meilano, Irwan., Abidin, Hasanuddin Z., Andreas, Heri., Gumilar, Irwan., Sarsito, Dina., Hanifa, Rahma., Rino, Harjono, Hery., Kato, Teruyuki., Kimata, Fumiaki., Fukuda, and Yoichi. 2012. Slip Rate Estimation of the Lembang Fault West Java from From Geodetic Observation. Journal of Disaster Research, 7 (1).

Meilano, Irwan., Riyadi, Puti Nabila., Riqqi, Akhmad., Kuscahyadi, dan Febriana. 2020. Estimating the Casualties of the Earth- quake Caused by the Lembang Fault in Coblong, Bandung, Indonesia. IOP Conference Series Earth and Environmental Science, 500:012069. DOI: 10.1088/17551315/500/1/012069

Newcomb, K. R. dan McCann, W. R. 1987. Seismic History and Seismotectonics of the Sunda Arc. Journal of Geophysical Research, 92 (B1), pp 421-439. American Geophysical Union.

Nikolaidis, R. 2002. Observation of geodetic and seismic deformation with the Global Positioning System. University of California, San Diego.

Pusat Studi Gempa Nasional. 2017. Peta Sumber dan Bahaya Gempa Indonesia Tahun 2017. Bandung: Pusat Penelitian dan Pengembangan Permukiman, Kementerian PUPR.

Smith, Lindsay I. 2002. A tutorial on Principal Components Analysis. http://www.cs.otago. ac.nz/cosc453/student_tutorials/principal_ components.pdf\&ved=2ahUKEwjS8tyD _qnpAhX083MBHd5ODKcQFjAAegQIBR AB\&usg=AOvVaw0tFD6xWRO5Mooq pyCbaMST

Supartoyo, Surono, dan Putranto, E.T., 2014. Katalog Gempabumi Merusak di Indonesia Tahun 1612 - 2014 (edisi kelima). Bandung. Pusat Vulkanologi dan Mitigasi Bencana Geologi.

Widiyantoro S., E. Gunawan, A. Muhari, N. Rawlinson, J. Mori, N. R. Hanifa, S. Susilo, P. Supendi, H. A. Shiddiqi, A. D. Nugraha, and H. E. Putra. 2020. Implications for megathrust earthquakes and tsunamis from seismic gaps south of Java indonesia. Nature, 10:15274.

Yabuki, T. and Matsu'ura, M. 1992. Geodetic data inversion using a Bayesian information criterion for spatial distribution of fault slip. Geophysical Journal International, 109, 363-375. 